\title{
ESSAY
}

\section{A flight of fancy}

Henry Nicholls wonders how things would be different had Charles Darwin given in to
pressure from his publisher to rewrite Origin of Species into a popular book about pigeons.

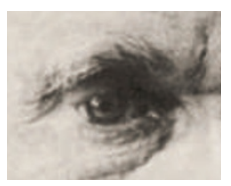

Darwin200
"Pigeons indeed," huffed Charles Darwin, his brow furrowed as he read to the end of a letter and laid it down on his desk.

The letter contained feedback from his publisher John Murray on a draft of what would become On the Origin of Species by Means of Natural Selection. Murray had farmed out copies of the manuscript to a couple of his trusted advisers. One of them, a rural vicar and literary editor by the name of Whitwell Elwin, had not liked it all. "At every page, I was tantalized by the absence of the proofs," Elwin had written to Murray on 3 May 1859. In contrast to the Journal of Researches (later known as Voyage of the Beagle), which Elwin had found "one of the most charming books", Darwin had written this new work in a "much harder \& drier style".

Although opposed to the publication of what he saw as "a wild and foolish piece of imagination”, Elwin hadn't advised Murray to reject the manuscript outright. Instead, he had sought the advice of the geologist Charles Lyell. It was Lyell who said that the book should focus on Darwin's observations of pigeons "accompanied with a brief statement of his general principles" on natural selection. Indeed, Lyell had made a similar suggestion to Darwin back in May 1856 after being enchanted by Darwin's pigeons at Down House, Kent. "I wish you would publish some small fragment of your data [on] pigeons if you please \& so out with the theory \& let it take date - \& be cited - \& understood," he had written.

Elwin's final recommendation to Murray reiterated this wish: Darwin should deliver a slimmer volume that homed in on this one well-worked case study. "Every body is interested in pigeons," Elwin observed.

Before considering Darwin's response to that suggestion, it is worth taking a moment to reflect on what might have been On the Origin of Pigeons. Such a volume would, Elwin had suggested, "be reviewed in every journal in the kingdom \& would soon be on every table". He was probably right. Breeding 'fancy' pigeons was an extraordinarily popular pastime in Victorian Britain, with enthusiasts spanning the entire social spectrum, from the poorest

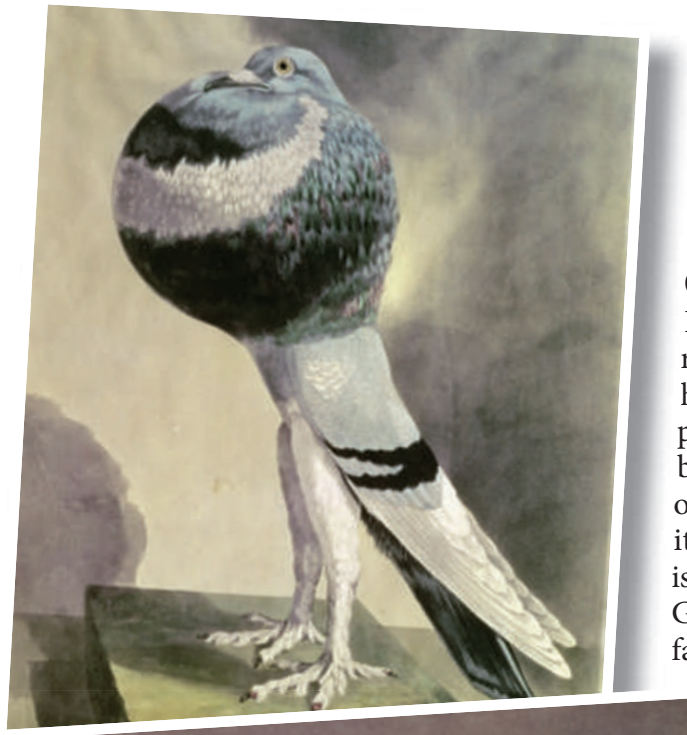

weavers in London's Spitalfields to Queen Victoria herself. But how effective would $O n$ the Origin of Pigeons have been as a vehicle for Darwin's ideas on evolution by natural selection?

\section{Common descent}

It was just four years before he received Murray's letter, in March 1855, that Darwin found himself drawn towards fancy pigeons. For the pigeon breeders, or fanciers, crossing different breeds was not just pointless (as mixed-race offspring lack the qualities of their parents), it bordered on heresy. So like the splendid isolation offered by the different islands of the Galápagos, the strict racial segregation the fanciers imposed on their birds ensured that every breed was effectively isolated from every other.

Despite the birds' striking physical differences, Darwin, in line with several other naturalists, suspected a single common ancestor for all the varieties - the rock pigeon Columba livia - and he began to gather evidence to support his hunch. Within months, he had mugged up on manuals, tailor-made a pigeon house for his garden and filled it with dozens of different breeds, describing them to Lyell as "the greatest treat, in my opinion, which can be offered to [a] human being". With abundant historical information at his fingertips, and by obtaining meticulous measure-

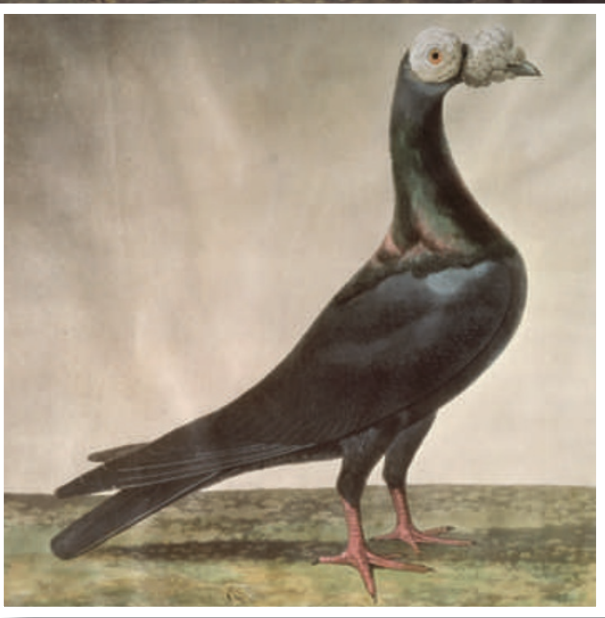

Despite their striking physical differences, Darwin suspected that the various breeds of 'fancy' pigeon shared a common ancestor. ments from adults, embryos and even blood corpuscles, he constructed a family tree for the pouters, carriers, runts, barbs, fantails, nuns and a dozen other spectacular fancy pigeon breeds.

Darwin's foray into breeding gave him yet more evidence in favour of the pigeons' common descent. A cross of any two varieties, he found, produced fertile offspring. What's more, the offspring of these crosses often sported characteristics not found in either parent but that did appear in the rock pigeon. So in spite of their extraordinary visible differences, some underlying sameness united all the fancy varieties. All this, and more, eventually wound up in his 1868 book on The Variation of Animals and Plants Under Domestication.

Darwin's pigeons also served another 
purpose, one that's harder to detect in his published writings. By crossing different breeds and observing how traits were passed from one generation to the next, he hoped to bring some clarity to the frequently confused thinking on inheritance. Research on the mass of pigeon skeletons and skins that Darwin left to the Natural History Museum in London promises to shed fresh light on the precise lines of enquiry he pursued. But even with more information, seeing pigeons as Darwin saw them will be extraordinarily tricky because it requires unimagining so much of what we now take for granted. At the very least, you must unravel the double-helix, knock out the gene and banish the concept of chromosomes. Then you must populate your mind with what are, by today's standards, some very strange notions.

Take pre-potency, for example, the idea that when two different breeds are crossed, one makes a greater contribution than the other to the offspring. In a version of this, known as Yarrell's law, it was proposed that the older breed would always dictate the characteristics of the next generation. Another commonly held belief was that males were responsible for defining the external characteristics of the offspring and females the internal features.

Evidence from Darwin's notebooks, letters

Publisher John Murray (top) relayed to Darwin the advice of Charles Lyell, who felt that pigeons would best communicate his theory of natural selection. and unpublished manuscripts suggests that the outcomes of the crosses he performed ran counter to each of these widely held beliefs. Unfortunately, however, the complex genetic basis for the traits he was looking at meant his pigeon crosses failed to reveal the true particulate nature of inheritance, something that would have to wait for the discovery of Gregor Mendel's work at the turn of the century.

\section{Unnatural selection}

Although Darwin's work on pigeons failed to unravel many of the mysteries surrounding inheritance, it did make a marvellously persuasive case for the origin of new varieties by means of artificial selection. From there, it was a simple step to argue, by analogy, for the origin of species by means of natural selection. But would On the Origin of Pigeons, had

\section{"On the Origin of} Pigeons would have failed to capture the extraordinary scope of natural selection." would have failed to capture the extraordinary scope of natural selection's explanatory power.

That was Darwin's crucial aim - to demonstrate the impact of natural selection "on geograph. distribution, palaeontology, classification Hybridism, domestic animals \& plants...”. In 1856 , he set about writing the book that would do this, a work he called Natural Selection. He was still at it almost two years later when he received the now infamous letter from Alfred Russel Wallace that outlined the same idea. This unexpected circumstance forced Darwin to shelve what would have been a massive, multivolume magnum opus (about two-thirds of which he had already written), and work furiously for the next ten months to bash out a shorter 'abstract'.

So how did Darwin feel that morning when he received Elwin's feedback on this condensed version? Probably a bit it been written, have conveyed the enormity of Darwin's idea?

A few of the more observant and imaginative readers might well have seen Darwin's broader message. For many more, however, the wonder of the fancy breeds would have been the main show, and the link between artificial and natural selection an unnecessary distraction. Perhaps more importantly, On the Origin of Pigeons rotten. Elwin's criticisms - that it was thin on evidence and stylistically wanting - hit on the two weaknesses that he often worried about. But if he did contemplate writing the desired pigeon book, it was not for long. "It is my deliberate conviction that both Lyells \& Mr Elwyns suggestions ... are impracticable," he wrote back to Murray. "I have done my best. Others might, I have no doubt, done the job better, if they had my materials; but that is no help."

Persuaded by Darwin's determination, Murray agreed to publish, making little editorial input other than to clip the first five words from the proposed title - An Abstract of an Essay on the Origin of Species and Varieties Through Natural Selection. Darwin subsequently made a few further tweaks to give us the title we celebrate this year.

Darwin's gambit - to convince his audience of evolution by natural selection by showing the extraordinary breadth of its explanatory power - proved remarkably effective. We owe a debt of gratitude to Wallace for denying us the thudding great tomes of Natural Selection and to Darwin for depriving us of a pithy little book on pigeons. On the Origin, with its light touch and wide-ranging content, sits comfortably between these two extremes.

Henry Nicholls is a science writer who lives in London. His most recent book is Lonesome George: The Life and Loves of a Conservation Icon.

For further reading, see http://tinyurl.com/bwjsl5. For more on Darwin, see www.nature.com/darwin. Listen to Henry Nicholls on the Nature podcast at www.nature.com/nature/podcast. 